\title{
Reconstructing meaning in bereavement: summary of a research program
}

\author{
Retomada de sentido no luto: resumo \\ de um programa de pesquisa
}

Robert A. NEIMEYER

\begin{abstract}
Bereavement, in the form of the loss of a significant attachment figure, disrupts the self-narratives of survivors and typically pitches them into an unsought quest for meaning in the loss, as well as in their changed lives. A growing body of research on diverse groups - bereaved parents, young people, elderly - suffering loss through both natural and violent death, documents the link between the inability to find meaning in the experience and the intensity of complicated grief they suffer. This article reviews the literature, arguing that the processes of sense-making and benefit-finding play a crucial role in bereavement adaptation for many of the bereaved, and accordingly, that interventions that facilitate processes of meaning reconstruction can support effective psychotherapy for those struggling with intense and prolonged grief.
\end{abstract}

Uniterms: Bereavement. Death. Meaning in loss

\section{Resumo}

O luto, na forma de perda através da morte de uma figura com quem se tinh a vínculo significativo, interrompe as autonarrativas dos sobreviventes e, geralmente, os coloca em uma busca involuntária pelo sentido da perda bem como de suas vidas alteradas. O número crescente de pesquisas envolvendo diversos grupos - pais, jovens e idosos em luto-que sofrem a perda através de morte natural eviolenta, documenta a associação entre a incapacidade de encontrar sentido na experiência e a intensidade da dor complexa que essas pessoas sentem. Este artigo revisa esta literatura, argumentando que os processos de compreensão e encontro de ajuda desempenham um papel crucial na adaptação do luto para muitas das pessoas neste processo e, consequentemente, que as intervenções que facilitam os processos de retomada de sentido podem sustentar uma psicoterapia eficaz para aqueles com dificuldades e dor intensa e prolongada.

Unitermos: Luto. Morte. Significado de perda.

To live is to suffer; to survive is to find some meaning in the suffering.

Friedrich Nietzsche

There is not one big cosmic meaning for all, there is only the meaning we each give to our life, an individual meaning, an individual plot, like an individual novel, a book for each person.

Anais Nin

To a far greater extent than other species of animals, we as human beings are distinguished by living

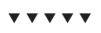

1 University of Memphis, Department of Psychology. 6400 Innovation Drive, Rm 202, 38152, Memphis, TN, USA. E-mail: <neimeyer@memphis.edu>. 
not only in a present, physical world, but also in a world populated by long-term memories, long-range anticipations, reflections, goals, interpretations, hopes, regrets, beliefs, metaphors - in a word, meanings. Indeed, it is this capacity to construct and inhabit a symbolic world that permits us to embroider experience with language, to speak and be heard, to relate, revise and resist stories of the events of our day or the entirety of our lives. In "acts of meaning," as Jerome Bruner (1990) once phrased it, we seek an order, a foundation, a plan, a significance in human existence, and particularly our own.

And yet, at times, the stubborn physicality of the present moment asserts itself, sometimes brutally, stressing or shredding the delicate tissue of meaning on which our all-too-vulnerable assumptive worlds depend. Never is this clearer than when these fragile expectations, understandings and illusions meet with incompatible yet incontrovertible occurrences - the diagnosis of our own serious illness, betrayal by an intimate partner, news of a loved one's sudden death. At such moments we can feel cast into a world that is alien, unimaginable, uninhabitable, one that radically shakes or severs those taken-for-granted "realities" in which we are rooted and on which we rely for a sense of secure purpose and connection. My intent in writing this brief article is to invite attention to this potential crisis of meaning in the context of bereavement, as well as to offer some principles for assisting with its reconstruction.

\section{Loss and the quest for meaning}

Just as philosophers, linguists and theologians emphasize the role of meaning in human life, so too do many psychologists. In particular, both classical and contemporary constructivists (Kelly, 1955/1991; Neimeyer, 2000, 2009) focus on the processes by which people punctuate the seamless flow of life events, organizing them into meaningful episodes and discerning in them recurrent themes that give them personal significance and lead them to seek validation in their relationships with others. Viewed in narrative terms, we ultimately construct a life story that is distinctively our own, though it necessarily draws on the social discourses of our place and time. The result is a self-narrative (Neimeyer, 2004b), defined as "an overarching cognitive-affective-behavioral structure that organizes the 'micro-narratives' of everyday life into a 'macro-narrative' that consolidates our selfunderstanding, establishes our characteristic range of emotions and goals and guides our performance on the stage of the social world" (p.53). From this perspective, identity can be seen as a narrative achievement, as our sense of self is established through the stories that we tell about ourselves and relevant others, the stories that others tell about us and the stories we enact in their presence. Importantly, it is this very self-narrative that is profoundly shaken by "seismic" life events such as the death of a loved one, instigating the processes of reaffirmation, repair or replacement of the basic plot and theme of one's life story (Calhoun \& Tedeschi, 2006; Neimeyer, 2006).

Consider the experience of Gayle, struggling in the aftermath of the death of her son, Max, in a road accident on his way back to college. As a deeply thoughtful young man, exploring both Eastern and Western traditions of wisdom, Max had been drawn in the months before his death to the music of Cloud Cult, whose songs, like Journey of the Featherless, captured in a youthful, modern idiom the cosmic "flight" of sojourners skyward, beyond social convention, while in related tracks on the same CD, the voices of the performers intoned repeatedly, Ilove my mother/Ilove my father/And when it's my time to go/ I want you to know/I love you all. When Max was the only one to die in the rollover of the SUV in which he was riding as a passenger, the singed backpack containing his reflective journal and poetry was one of the few things that escaped the flaming wreckage. As she searched desperately for some meaning in the seemingly senseless death of her son, Gayle took heart in the Cloud Cult music found in Max's CD player in his bedroom, in the philosophic tone of the poetry and prose in his miraculously salvaged journal, and in the survival of Max's girlfriend in the same accident, as the young woman herself was moved to a deep search for significance in the months that followed the tragedy. Together, she and Gayle sought, and found, some sense in the death through an eclectic spiritual narrative centering on their mutual "soul contracting" with Max, between incarnations, to undergo this trial together in their present lives, so that each might learn what it had to teach them in their respective journeys. 
Reinforced by a series of memorial services, rituals, and consultations with mediums and various spiritual guides, the new narrative of the meaning of Max's life and death consolidated into a stable resource for not only the two women, but also for an entire community of relevant others, who joined in spontaneous "strike force philanthropy" in honor of Max, thereby extending the story beyond one of consolation to one fostering social action to mitigate suffering in the world, including a massive medical aid effort to survivors of the earthquake in Haiti.

In the aftermath of life-altering loss, the bereaved are commonly precipitated into a search for meaning at levels that range from the practical (How did my loved one die?) through the relational (Who am I, now that I am no longer a spouse?) to the spiritual or existential (Why did God allow this to happen?). How - and whether - we engage these questions and resolve or simply stop asking them, shapes how we accommodate the loss itself and who we become in light of it. In Gayle's case, anguished and intermittent questioning impelled her forward in her search, ultimately deepening and broadening her existing sense of cosmic purpose, and galvanizing her efforts to live authentically and compassionately in relation to others who shared the same objective loss, or who faced losses and struggles in their own lives. The result was a revised self-narrative that found significance in the event story of her son's death, as well as in the back story of his life, braided together intimately with her own.

A growing body of research on meaning reconstruction in the wake of loss supports the broad outline of this model and is beginning to add clinically useful detail to our understanding of how the bereaved negotiate the unwelcome change introduced into their lives by the loss, both for better and for worse and how we as professional helpers might best support their search for significance. It is worth bearing in mind at the outset, however, that loss does not inevitably decimate survivors' self-narratives and mandate a revision or reappraisal of life meanings, as many will find consolation in systems of secular and spiritual beliefs and practices that have served them well in the past (Attig, 2000). Indeed, especially when the deaths of loved ones are relatively normative and anticipated, only a minority of the bereaved reports searching for meaning in the experience and the absence of such a search is one predictor of a positive bereavement outcome (Coleman \& Neimeyer, 2010; Davis, Wortman, Lehman \& Silver, 2000). Even in the case of normative losses such as late-in-life widowhood, however, evidence suggests that a significant minority of survivors struggles to find meaning in their loss over an extended period of time (Bonanno, Wortman \& Nesse, 2004). Moreover, in this same prospective, longitudinal study of widows and widowers, those who reported a more intense search for meaning in the loss, 6 and 18 months after the death, evidenced a more painful and prolonged reaction of grief throughout 4 years of bereavement (Coleman \& Neimeyer, 2010). Indeed, research on complicated, prolonged grief disorder documents that a struggle with meaninglessness is a cardinal marker of debilitating bereavement reactions across many populations (Prigerson et al., 2009). In a large cohort of bereaved young adults suffering a variety of losses, for example, inability to "make sense" of the death was associated with marked and preoccupying separation distress throughout the first two years of adaptation (Holland, Currier \& Neimeyer, 2006).

When losses are more objectively traumatic, data suggest that a search for sense or significance in the loss is more common, characterizing the majority of those bereaved by the sudden death of a family member, or parents who lose a child (Davis et al., 2000). Evidence demonstrates that a crisis of meaning is especially acute for those bereaved by suicide, homicide or fatal accident, who report a far more intense struggle to make sense of the loss than do those whose loved ones died of natural causes. Moreover, the role of sense making - a key form of meaning-making - is so prominent in accounting for the complex symptoms of grief experienced by the former group, that it functions as a nearly perfect mediator of the impact of violent death, accounting for virtually all of the difference between those bereaved by the traumatic as opposed to natural death of their loved ones (Currier, Holland \& Neimeyer, 2006).

Research on bereaved parents reinforces the powerful role of meaning-making in predicting bereavement outcome. Studying a large group of mothers and fathers whose children had died, anywhere from a few months to many years earlier, Keesee, Currier and Neimeyer (2008) found that the passage of time, the 
gender of the parent and even whether the child died a natural or violent death, accounted for little of their subsequent adaptation, whether assessed in terms of normative grief symptoms (e.g. sadness and missing the child) or complicated grief (e.g. an ongoing inability to care about other people and long-term disruption of functioning in work and family contexts). In contrast, their degree of sense-making proved to be a potent predictor of concurrent, complicated grief symptoms, accounting for 15 times more distress experienced by these parents than any of the above mentioned objective factors (Keesee et al., 2003). A further analysis, of qualitative responses to questions about the kinds of meanings made by these parents, also proved enlightening. Fully $45 \%$ of the parents confessed that they were unable to make sense of their child's death even 6 years later, on average, and over $20 \%$ could identify no unsought benefits (e.g. greater personal strength) to mitigate the great pain of the tragedy. Overall, parents discussed 32 distinct approaches to finding meaning in their child's death, 14 of which involved sense-making and 18 involved unsought benefits or a "silver lining" in the loss, each representing a means of finding meaning in a tragic experience. The most common sense-making themes involved religious beliefs (such as the conviction that the child's death was part of a divine plan or a belief in reunion in an afterlife), and the most common benefitfinding themes entailed an increase in the desire to help and compassion for others' suffering. Parents who invoked specific sense-making themes, including attributing the death to God's will or a belief that the child was no longer suffering, as well as those who reported benefits such as reordered life priorities, experienced fewer maladaptive grief symptoms (Lichtenthal, Currier, Neimeyer \& Keesee, 2010).

On the other hand, nothing guarantees that spirituality will serve as a defense against the challenges of bereavement; indeed, one's spiritual orientation may itself suffer as a function of the assault on meaning posed by tragic loss. Burke, Neimeyer, McDevitt-Murphy, Ippolito and Roberts (2011) recently reported, for example, that African Americans, bereaved by the homicide of a loved one, frequently struggled with complex grief, and that this form of distress from bereavement predicted subsequent struggles with feeling abandoned by God and the faith community some six months later.
Finally, it is worth underscoring that adaptation to bereavement entails more than simply surmounting painful symptoms of grief and depression, insofar as significant numbers of people report resilience or even personal growth after loss, outcomes that are no less important to assess and facilitate (Neimeyer, Hogan \& Laurie, 2008). Here too, it seems likely that meaningmaking contributes to adaptive outcomes, as longitudinal research on widowhood demonstrates that sense-making in the first 6 months of loss predicts higher levels of positive effect and well-being a full 4 years after the death of a spouse (Coleman \& Neimeyer, 2010). Fostering reconstruction of a world of meaning would therefore seem to be a therapeutic priority for many bereaved clients, one that could bring benefits, not only in alleviating complicated symptoms of grief, but also in renewing a sense of hope and self-efficacy in their changed lives. The recent development of a carefully validated, multidimensional measure of the extent to which a survivor can integrate his or her loss into a fuller system of personal meaning, should advance this work in both clinical and research contexts (Holland et al., 2010).

How might such meaning reconstruction be facilitated in the context of support groups or psychotherapy? Research on bereavement professionals indicates that they routinely draw on a host of strategies to advance this goal, beginning with fostering a sense of presence to the needs of the grieving client, progressing to a delicate attention to the process of therapy and finding ultimate expression in a great variety of specific therapeutic procedures (Currier, Holland \& Neimeyer, 2008). Presence, in the view of these practitioners, entails chiefly cultivating a safe and supportive relationship, one characterized by deep and empathic listening. Process goals involve psychoeducation about loss, promoting the client's telling of his or her story, exploration of spiritual and existential concerns, processing and regulation of emotions and utilization of existing strengths and resources, and finally, concrete therapeutic procedures include a wide range of narrative, ritual, expressive and pastoral methods for helping clients make sense of the loss and their changed lives, which are beginning to receive support as evidencebased treatments in randomized, controlled trials (Lichtenthal \& Cruess, 2010; Wagner, Knaevelsrud \& 
Maercker, 2006). Accordingly, a good deal of attention has been paid, within a framework of meaning reconstruction, to explaining and exemplifying these methods, in such diverse media as books (Neimeyer, 2001 b; 2009), chapters (Neimeyer, 2006; Neimeyer \& Arvay, 2004; Neimeyer, van Dyke \& Pennebaker, 2009), articles in journals (Neimeyer, 2001a; Neimeyer, Burke, Mackay \& Stringer, 2010), training videos (Neimeyer, 2004a; 2008) and online continuing education programs (Neimeyer, 2010) for grief professionals, as well as self-help resources for bereaved clients (Neimeyer, 2002).

In summary, a constructivist focus on the role of meaning-making in bereavement has received increasing attention in both research and clinical literature, as evidence increasingly documents the important role of reaffirming or reorganizing a world of meaning that has been challenged by loss. I hope that this brief introduction to this work encourages investigators and practitioners to deal with the significance of bereavement as well as its attendant symptomatology and shed further light on the efforts of many of the bereaved to reconstruct their life narratives in the wake of loss.

\section{References}

Attig, T. (2000). The heart of grief. New York: Oxford.

Bonanno, G. A., Wortman, C. B., \& Nesse, R. M. (2004). Prospective patterns of resilience and maladjustment during widowhood. Psychology and Aging, 19, 260-271.

Bruner, J. (1990). Acts of meaning. Mass.: Harvard University Press.

Burke, L. A., Neimeyer, R. A., McDevitt-Murphy, M. E., Ippolito, M., \& Roberts, J. M. (2011). Faith in the wake of homicide: religious coping and bereavement distress in an African American sample. International Journal for the Psychology of Religion, in press.

Calhoun, L., \& Tedeschi, R. G. (Eds.). (2006). Handbook of posttraumatic growth. Mahwah, NJ: Lawrence Erlbaum.

Coleman, R. A., \& Neimeyer, R. A. (2010). Measuring meaning: searching for and making sense of spousal loss in later life. Death Studies, 34, 804-834.

Currier, J. M., Holland, J. M., Coleman, R., \& Neimeyer, R. A. (2007). Bereavement following violent death: an assault on life and meaning. In R. Stevenson \& G. Cox (Eds.), Perspectives on violence and violent death. Amityville, NY: Baywood.

Currier, J. M., Holland, J., \& Neimeyer, R. A. (2006). Sense making, grief and the experience of violent loss: toward a mediational model. Death Studies, 30, 403-428.
Currier, J. M., Holland, J. M., \& Neimeyer, R. A. (2008). Making sense of loss: a content analysis of end-of-life practitioners' therapeutic approaches. Omega, 57, 121-141.

Davis, C. G., Wortman, C. B., Lehman, D. R., \& Silver, R. C. (2000). Searching for meaning in loss: are clinical assumptions correct? Death Studies, 24, 497-540.

Gardner, H., (1993) Multiple intelligences: the theory in practice. New York: Basic.

Holland, J., Currier, J., \& Neimeyer, R. A. (2006). Meaning reconstruction in the first two years of bereavement: The role of sense-making and benefit-finding. Omega, 53, 173-191.

Holland, J. M., Currier, J. M., Coleman, R. A., \& Neimeyer, R. A. (2010). The Integration of Stressful Life Experiences Scale (ISLES): development and initial validation of a new measure. International Journal of Stress Management, 17, 325-352.

Janoff-Bulman, R., \& Berg, M. (1998). Disillusionment and the creation of value. In J. Harvey (Ed.), Perspectives on loss (pp.33-47). Philadelphia: Bruner/Mazel.

Keesee, N. J., Currier, J. M., \& Neimeyer, R. A. (2008). Predictors of grief following the death of one's child: The contribution of finding meaning. Journal of Clinical Psychology, 64, 1145-1163.

Kelly, G. A. (1955/1991). The psychology of personal constructs. New York: Routledge.

Lichtenthal, W. G., \& Cruess, D. G. (2010). Effects of directed written disclosure on grief and distress symptoms among bereaved individuals. Death Studies, 34, 475-499.

Lichtenthal, W. G., Currier, J. M., Neimeyer, R. A., \& Keesee, N. J. (2010). Sense and significance: a mixed methods examination of meaning-making following the loss of one's child. Journal of Clinical Psychology, 66, 791-812.

Neimeyer, R. A. (2000). Narrative disruptions in the construction of self. In R. A. Neimeyer \& J. D. Raskin (Eds.), Constructions of disorder: Meaning making frameworks for psychotherapy (pp.207-241). Washington, D. C.: American Psychological Association.

Neimeyer, R. A. (2001a). Reauthoring life narratives: grief therapy as meaning reconstruction. Israel Journal of Psychiatry, 38, 171-183.

Neimeyer, R. A. (Ed.). (2001b). Meaning reconstruction and the experience of loss. Washington, D.C.: American Psychological Association.

Neimeyer, R. A. (2002). Lessons of loss: a guide to coping. Memphis, TN: Center for the Study of Loss and Transition.

Neimeyer, R. A. (2004a). Constructivist psychotherapy. On Series 1: Systems of psychotherapy [DVD]. Washington, DC: American Psychological Association.

Neimeyer, R. A. (2004b). Fostering posttraumatic growth: a narrative contribution. Psychological Inquiry, 15, 53-59.

Neimeyer, R. A. (2006). Re-storying loss: fostering growth in the posttraumatic narrative. In L. Calhoun \& R. G. Tedeschi (Eds.), Handbook of posttraumatic growth: Research and practice. Mahwah, NJ: Lawrence Erlbaum. 
Neimeyer, R. A. (2008). Constructivist Psychotherapy over time [DVD]. Washington, DC: American Psychological Association.

Neimeyer, R. A. (2009). Constructivist psychotherapy. New York: Routledge.

Neimeyer, R. A. (2010). Strategies of grief therapy [online continuing education program]: Washington, DC: American Psychological Association.

Neimeyer, R. A., \& Arvay, M. J. (2004). Performing the self: therapeutic enactment and the narrative integration of traumatic loss. In H. Hermans \& G. Dimaggio (Eds.), The dialogical self in psychotherapy (pp.173-189). New York: Routledge.

Neimeyer, R. A., Burke, L., Mackay, M., \& Stringer, J. (2010). Grief therapy and the reconstruction of meaning: from principles to practice. Journal of Contemporary Psychotherapy, 40, 73-83.

Neimeyer, R. A., Hogan, N., \& Laurie, A. (2008). The measurement of grief: psychometric considerations in the assessment of reactions to bereavement. In $\mathrm{M}$. Stroebe, R. O. Hansson, H. Schut \& W. Stroebe (Eds.), Handbook ofbereavement research:21stcenturyperspectives (pp.133-186). Washington, DC: American Psychological Association.

Neimeyer, R. A., van Dyke, J. G., \& Pennebaker, J. W. (2009). Narrative medicine: Writing through bereavement. In H. Chochinov \& W. Breitbart (Eds.), Handbook of psychiatry in palliative medicine (pp.454-469). New York: Oxford.

Prigerson, H. G., Horowitz, M. J., Jacobs, S. C., Parkes, C. M., Aslan, M., Goodkin, K., et al. (2009). Prolonged grief disorder: Psychometric validation of criteria proposed for DSM-V and ICD-11. PLoS Medicine, 6, 1-12.

Wagner, B., Knaevelsrud, C., \& Maercker, A. (2006). Internetbased cognitive-behavioral therapy for complicated grief: a randomized controlled trial. Death Studies, 30, 429-453.

Received on: 4/4/2011

Approved on: 18/5/2011 